\title{
18
}

\section{Getting Personal: Reflexivity, Positionality, and Feminist Research}

\author{
Kim V. L. England \\ 1994. The Professional Geographer 46 (1), 80-9. ${ }^{1}$
}

Think we must. Let us think in offices; in omnibuses; while we are standing in the crowd watching Coronations and Lord Mayor's Shows; let us think as we pass the Cenotaph; and in Whitehall; in the gallery of the House of Commons; in the Law Courts; let us think at baptisms and marriages and funerals. Let us never cease from thinking - what is this 'civilization' in which we find ourselves? What are these professions and why should we make money out of them? Where in short is it leading us, the procession of the sons of educated men? (Woolf, 1938, 62-63)

Virginia Woolf's words speak to the process of making geography. She urges us to think about and to reflect on the spatial fabric of everyday life. She asks us to consider the structure of our social relations and how we are accountable for them and how our actions perpetuate those relations. She wants us to consider how things could be different.

In this paper I discuss the process of making geography at a time when social scientists are increasingly suspicious of the possibility of "objectivity" and value-free research, and when the acceptance of the socially constructed and situated nature of knowledge is increasingly commonplace [among social scientists]. In particular, I

\footnotetext{
${ }^{1}$ Reprinted with permission from Kim V. L. England . The chapter was originally published in "Getting personal: Reflexivity, positionality, and feminist research." 1994. The Professional Geographer 46(1), pp. 80-89, Wiley-Blackwell Publishing Ltd.
} 
focus on and problematize fieldwork, a term that I use as shorthand for those research methods where the researcher directly confronts those who are researched. ${ }^{2}$ I approach this task as a feminist, but recognize that many of the issues that I am struggling with exist for researchers of other philosophical-political-methodological stripes.

\section{Troubling Questions, Professional Armor, and the Threat of the Personal}

Feminism and poststructuralism have opened up geography to voices other than those of white, Western, middle-class, heterosexual men. This allows for a geography which, as Lowe and Short put it, "neither dismisses nor denies structural factors, but allows a range of voices to speak" $(1990,8)$. While this makes for a more complete analysis of the complexities of the social world, it also raises new ethical issues. In our rush to be more inclusive and conceptualize difference and diversity, might we be guilty of appropriating the voices of "others"? How do we deal with this when planning and conducting our research? And can we incorporate the voices of "others" without colonizing them in a manner that reinforces patterns of domination? Can these types of dilemmas be resolved, and if so, how? Geographers have had relatively little to say about these troubling questions (important exceptions include Miles and Crush, 1993; Moss, et al. 1993; Pile, 1991; Sidaway, 1992; S. J. Smith, 1988). Instead, anthropologists and, to a lesser extent, sociologists have been leading the discussion on the ethics of fieldwork. ${ }^{3}$

Feminism and the so-called postmodern turn in the social sciences represent a serious challenge to the methodological hegemony of neopositivist empiricism. One of the main attractions of "traditional" neopositivist methods is that they provide a firmly anchored epistemological security from which to venture out and conduct research. Neopositivist empiricism specifies a strict dichotomy between object and subject as a prerequisite for objectivity. Such an epistemology is supported by methods that position the researcher as an omnipotent expert in control of both passive research subjects and the research process. Years of positivist-inspired training have taught us that impersonal, neutral detachment is an important criterion for good research. In these discussions of detachment, distance, and impartiality, the personal is reduced to a mere nuisance or a possible threat to objectivity. This threat is easily dealt with. The neopositivist's professional armor includes a carefully constructed public self as a mysterious, impartial outsider, an observer freed of personality and bias.

${ }^{2}$ This includes those methods that are variously described as feminist, qualitative, interpretive, intensive, ethnographic, and critical. I recognize that each of these has its own unique contribution.

${ }^{3}$ Of course, the primacy of anthropology here is partly related to classical anthropology's colonial heritage when anthropologists were often members of the colonial regime that dominated the country they studied (Driver, 1992). 
Perhaps Stanley and Wise $(1993,66)$ put it best when they said the "western industrial scientific approach values the orderly, rational, quantifiable, predictable, abstract and theoretical: feminism spat in its eye." The openness and culturally constructed nature of the social world, peppered with contradictions and complexities, needs to be embraced, not dismissed. This means that "the field" is constantly changing and that researchers may find that they have to maneuver around unexpected circumstances. The result is research where the only inevitability seems to be unreliability and unpredictability. This, in turn, ignites the need for a broader, less rigid conception of the "appropriate" method that allows the researcher the flexibility to be more open to the challenges of fieldwork (Hondagneu-Sotelo, 1988; Opie, 1992).

For me, part of the feminist project has been to dismantle the smokescreen surrounding the canons of neopositivist research - impartiality and objectivist neutrality - which supposedly prevent the researcher from contaminating the data (and, presumably, vice versa). As well as being our object of inquiry, the world is an intersubjective creation and, as such, we cannot put our commonsense knowledge of social structures to one side. This immediately problematizes the observational distance of neopositivism because, as Stanley and Wise $(1993,168)$ tell us, "treating people like objects - sex objects or research objects - is morally unjustifiable." Their point is that those who are researched should be treated like people and not as mere mines of information to be exploited by the researcher as the neutral collector of "facts."

In general, relationships with the researched may be reciprocal, asymmetrical, or potentially exploitative; and the researcher can adopt a stance of intimidation, ingratiation, self-promotion, or supplication (S. J. Smith, 1988). Most feminists usually favor the role of supplicant, seeking reciprocal relationships based on empathy and mutual respect, and often sharing their knowledge with those they research. Supplication involves exposing and exploiting weaknesses regarding dependence on whoever is being researched for information and guidance. Thus the researcher explicitly acknowledges her/his reliance on the research subject to provide insight into the subtle nuances of meaning that structure and shape everyday lives. Fieldwork for the researcher-as-supplicant is predicated upon an unequivocal acceptance that the knowledge of the person being researched (at least regarding the particular questions being asked) is greater than that of the researcher. Essentially, the appeal of supplication lies in its potential for dealing with asymmetrical and potentially exploitative power relations by shifting a lot of power over to the researched.

The intersubjective nature of social life means that the researcher and the people being researched have shared meanings and we should seek methods that develop this advantage. We can attempt to achieve an understanding of how social life is constituted by engaging in real or constructed dialogues in order to understand the people studied in their own terms (sometimes described as the insiders' view); hence the recent efforts to retrieve qualitative methods from the margins of social science. 
These methods offer the opportunity "to convey the inner life and texture of the diverse social enclaves and personal circumstances of societies" (Jackson, 1985, 157).

In essence I am arguing for a geography in which intersubjectivity and reflexivity play a central role. Reflexivity is often misunderstood as "a confession to salacious indiscretions," "mere navel gazing," and even "narcissistic and egoistic," the implication being that the researcher let the veil of objectivist neutrality slip (Okely, 1992). Rather, reflexivity is self-critical sympathetic introspection and the selfconscious analytical scrutiny of the self as researcher. Indeed reflexivity is critical to the conduct of fieldwork; it induces self-discovery and can lead to insights and new hypotheses about the research questions. A more reflexive and flexible approach to fieldwork allows the researcher to be more open to any challenges to their theoretical position that fieldwork almost inevitably raises. Certainly a more reflexive geography must require careful consideration of the consequences of the interactions with those being investigated. And the reflexive "I" of the researcher dismisses the observational distance of neopositivism and subverts the idea of the observer as an impersonal machine (Hondagneu-Sotelo, 1988; Okely, 1992; Opie, 1992).

\section{Failed Research?}

In the social sciences the lore of objectivity relies on the separation of the intellectual project from its process of production. The false paths, the endless labors, the turns now this way and now that, the theories abandoned, and the data collected but never presented - all lie concealed behind the finished product. The article, the book, the text is evaluated on its own merits, independent of how it emerged. We are taught not to confound the process of discovery with the process of justification (Burawoy, 1991, 8).

A further characteristic of neopositivist empiricism, as Burawoy indicates, is to ignore the actual making of geography. The concerns associated with doing research are usually ignored and accounts are produced from which the personal is banished. However, research is a process not just a product. Part of this process involves reflecting on, and learning from past research experiences, being able to re-evaluate our research critically, and, perhaps deciding, for various reasons, to abandon a research project. In short, I see research as an ongoing, intersubjective (or more broadly, a dialogic ${ }^{4}$ ) activity, and it is in this spirit that I want to discuss my dilemmas about "doing" a recent research project about lesbians in Toronto.

${ }^{4}$ Dialogism is Mikhail Bakhtin's (1986) theory about encountering "otherness" through the potential of dialogue between people (or with oneself). It involves the continual interaction between meanings, each of which has the potential of conditioning the others. Dialogism turns on the notion that people's responses are conditional and human circumstances are contingent (Folch-Serra, 1990). 
Questions relating to sexualities have been placed firmly on the research agenda of cultural and feminist studies (Crimp, 1992; de Lauretis, 1991; D'Emilio, 1992; Douglas, 1990; Gamson, 1991; Grosz, 1989; Ross, 1990) and geography (Bell, 1991; Geltmaker, 1992; Jackson, 1989, 1991; Knopp, 1987, 1990, 1992; Valentine, 1993a, 1993b). In the last few years I have read this work with great interest, but have been disappointed that geographers have paid very little attention to lesbians (but see, Adler and Brenner, 1992; Peake, 1993; Valentine, 1993a, 1993b; and Winchester and White, 1988). Living in a city with a large, gay male and lesbian population, I began to consider developing a research project about the extensive lesbian communities of Toronto.

Most previous geographical work on sexual identities has focused on the residential geography of gay men, especially their role in inner city revival. Inspired by Adler and Brenner's (1992) work on locating and characterizing the lesbian neighborhoods of a United States city, I used publicly available information (for example, "The Pink Pages: Toronto's Gay and Lesbian Directory") to compile and map the postal codes of lesbian-positive and lesbian-owned services and amenities in Toronto. However, I wanted to move beyond merely uncovering spatial patterns to explore the [social and spatial] implications and political consequences of this particular form of urban restructuring. Moreover, given that the most recent work in geography has advanced the notion that sexualities and space are mutually constructed (Geltmaker, 1992; Knopp, 1992; Valentine, 1993b), I felt it was important to explore how lesbian identities are constructed in and through [spatial relations].

Recently there has been a surge of interest in urban-based marginalized groups (see, for example, Laws, 1993; Rowe and Wolch, 1990; Ruddick, 1994; N. Smith, 1993). This interest broadens the horizons of geography, promises new research directions, and asks new questions. Generally, marginalized groups seem better able to exist autonomously, or even anonymously, in central cities than elsewhere. Certainly lesbian (and gay) territories and spaces are relatively insulated "safe places" away from heterosexism and homophobi[a]. ${ }^{5}$ They help provide a collective affirmation of identity, and allow for self-definition and self-exploration. However, the territorial claims of marginalized people are almost always contested more vigorously than those of more privileged groups. Despite gains made regarding prejudice and discrimination against numerous social groups, North America is still very heterosexist and homophobic. A chilling example of this was the extensive support of Amendment 9 in Oregon and Initiative 2 in Colorado (measures to overturn existing municipal laws protecting lesbians and gay men from discrimination in housing and employment) during the 1992 United States elections. So, for the minority of gay men and lesbians who live in self-identified neighborhoods, such self-[exposure] is not without its

5 Homophobia is the irrational fear and hatred of lesbians, gay men, and bisexuals. Heterosexism refers to the privileging of heterosexuality over other sexual identities, and the assumption that heterosexuality describes the world [or that it is the normal state of being]. 
dangers. The more lesbian and gay communities imprint and reinvent their identities in space, the more vulnerable they become to surveillance and containment. The most obvious and pernicious outcome of this is lesbian/gay baiting, bashing, and [...] murder. ${ }^{6}$

Sexual identities are negotiated, contested, and, quite literally, defended in and through space. Toronto's gay men and lesbians have been actively struggling against heterosexism and homophobia, and space has been a crucial component of this struggle. This is particularly apparent in lesbian and gay protests in "public" spaces: "homo kiss-ins" in shopping centers and straight bars; the annual lesbian and gay Pride Week Parade ${ }^{7}$; the frequent demonstrations around efforts to increase federal and provincial funding for AIDS prevention and research; and the recent, very loud demonstrations about the Canada Customs seizure of lesbian-explicit erotica. The cheers of "We're queer, we're here, get used to it" and "We're fags and dykes and we're here to stay" are noisy expressions of anger and affirmations of identity. Derogatory, "deviant" labels are turned on their head. T-shirts printed with "DYKE" or "I'm so queer I can't even think straight" reclaim meanings, disrupting and challenging the very process of categorizing and labelling. I read these events as lesbians (and gay men) occupying spaces that have been coded heterosexual. Spaces that are, supposedly, public are actually "heterosexed" spaces that are not intended to be spaces for lesbians or gay men. In short, these protests and resistances of heterosexism and homophobia are inherently territorial and capture the link between identity, resistance, and space.

Clearly, I think that the intersection of gender, sexual identities, and space is a very fruitful area for geographic research, but I have not really progressed much beyond merely thinking about doing this research. Initially I had three major concerns. First, is it ethical to identify the place of the study? Other research did not reveal the location of the community studied (Adler and Brenner, 1992; Lockard, 1985;

${ }^{6}$ Bashing appears to be on the increase in Toronto's most visible lesbian/gay neighborhood. Although bashing occurs throughout the year, it increases during the summer months when the main perpetrators - male youth - are out of school and come to this part of the city specifically to beat up gay men and lesbians. In 1990 the neighborhood community center established a "bashing hotline" so that victims can call for support, but also to $\log$ the details of the attack. This information has been used to prompt better police response and sensitivity. In the summer of 1993 the Toronto Metropolitan Police (in cooperation with the City of Toronto's committee on lesbian and gay issues) began a campaign against bashing. This campaign includes public service announcements and bus shelter advertising that announce that "Lesbian and gay bashing is a hate-motivated crime" and "Being lesbian or gay is not a crime. Bashing is."

${ }^{7}$ Pride Week is in June and marks the anniversary of the 1969 Stonewall riots in Greenwich Village. These riots, a reaction to continued police raids on gay bars, are generally considered to have been the beginning of the lesbian and gay rights movement in the United States. It is celebrated in a number of cities around the world. The parade has a 13-year history in Toronto, but it was not until 1993 that the police designated it a community event, exempting it from policing costs. 
Valentine, 1993a, 1993b). The reason was that some lesbians and gay men might not have wanted their communities "outed," and there was the real fear of reprisals, including physical attack. Second, I had concerns regarding my research assistant. I had employed her mainly because of her intellectual abilities, but also because she is a lesbian and, as such, provided me with another means by which I could gain entry into the lesbian world. The complicated layering and interweaving of power relations between myself, my research assistant, and the project became too much for me. I began to engage in what I can only describe as the mental hand-wringing of a straight, white (my research assistant is an Afro-Carribbean Canadian), feminist academic. Finally, I made a few preliminary phone calls to, for example, the organizing committee of the Pride Week Parade. My calls were not returned. It is probable that my timing was not very good; I made my calls a few weeks before the parade took place. Then, I began to think about Gerda Wekerle choosing to exclude a nonprofit housing project for native women from her study of Canadian women's housing cooperatives because the women "felt that they had already been over-studied" (1988, 103). I began to wonder whether, in an era of postmodernity marked by the celebration of "otherness" in which, as Suzanne Westenhoefer (a lesbian stand-up comic) wryly put it, "everyone wants to know a lesbian or to be with a lesbian or just to dress like one" (quoted in Salholz et al., 1993), we are engaged in the process of fetishizing "the other" (Probyn, 1993). Some of my discomfort about these three problems is captured by Liz Bondi:

the post-modern venture is a "new kind of gender tourism, whereby male theorists are able to take package trips into the world of femininity," in which they 'get a bit of the other' in the knowledge that they have return tickets to the safe, familiar and, above all, empowering terrain of masculinity (Bondi, 1990, 163).

I had to ask myself if I am guilty of something similar? Could I be accused of academic voyeurism? Am I trying to get on some cheap package tour of lesbianism in the hopes of gaining some fleeting understanding of, perhaps, the ultimate "other," given that lesbians are not male, heterosexual, not always middleclass, and often not white? In the midst of academic discourse on the problems of appropriating the voices of marginalized people and the perils of postcolonialism, I worried that I might be, albeit unintentionally, colonizing lesbians in some kind of academic neoimperialism.

\section{Appropriating the Voices of "Others"; Or When Reflexivity Is Not Enough}

The questions prompted by my "failed research" raise two sets of problems. The first revolves around the role of the researcher in the research encounter, the second around the nature of power relations in research about marginalized groups. I see fieldwork as a dialogical process in which the research situation is structured by both the researcher and the person being researched. Two issues flow from this point. The first is that the dialogical nature of research increases the probability that the 
research may be transformed by the input of the researched. The second is that dialogism means that the researcher is a visible and integral part of the research setting. Indeed, research is never complete "until it includes an understanding of the active role of the analyst's self which is exercised throughout the research process" (S. J. Smith, 1988, 18; also see Evans, 1988; Pile, 1991). We do not parachute into the field with empty heads and a few pencils or a tape-recorder in our pockets ready to record the "facts." As Stanley and Wise point out:

\begin{abstract}
Whether we like it or not, researchers remain human beings complete with all the usual assembly of feelings, failings, and moods. And all of those things influence how we feel and understand what is going on. Our consciousness is always the medium through which the research occurs; there is no method or technique of doing research other than through the medium of the researcher (Stanley and Wise, 1993, 157).
\end{abstract}

In short, the researcher is an instrument in her/his research and despite some commonalities (our education, and in many instances, our "race" and class), geographers are not part of some universal monolith. We are differently positioned subjects with different biographies; we are not dematerialized, disembodied entities. This subjectivity does influence our research as is illustrated by, for example, the extensive literature on how the gender of the researcher and those being researched influences the nature of fieldwork (Geiger, 1990; Herod, 1993; Oakley, 1981; Warren, 1988). Moreover, we have different personal histories and lived experiences, and so, as Carol Warren $(1988,7)$ makes clear, the researcher as "any person, without gender, personality, or historical location, who would objectively produce the same findings as any other person," is completely mythical.

The biography of the researcher directly affects fieldwork in two ways. First, different personal characteristics (be it that I am a white, straight English woman living in Canada or that I don't have a flair for quantitative methods) allow for certain insights, and as a consequence some researchers grasp some phenomena more easily and better than others. Indeed fieldwork "requires imagination and creativity and, as such, is not for everyone" (Mills and Withers, 1992, 163). At the same time, the everyday lives of the researched are doubly mediated by our presence and their response to our presence. I will illustrate this point with an example from my fieldwork experience. A couple of my previous projects have involved interviewing managers, almost all of whom are white men who are older than me. Occasionally they volunteered information that indicated that their firm had been engaged in practices that were, at best, marginally legal. My questions were not intended to elicit these responses (an example of the people being investigated shaping the nature of the research), and I have often wondered whether this information would have been so readily revealed to an older, more established male academic, especially one who did not supplicate, but instead intimidated the managers or was motivated by selfpromotion. This experience reflects Linda McDowell's assertion that because women may be perceived by men that they interview as "unthreatening or not 'official,' 
confidential documents (are) often made accessible, or difficult issues broached relatively freely" (McDowell, 1988, 167; also see McDowell, 1992a, 1992b). Certainly, I think that a combination of my biography and my tendency towards supplication gained me access to information that might not be given so willingly to a differently positioned academic. The researcher cannot conveniently tuck away the personal behind the professional, because fieldwork is personal. As Okely $(1992,2)$ notes "those who protect the self from scrutiny could as well be labelled as selfsatisfied and arrogant in presuming their presence and relations with others to be unproblematic." A researcher is positioned by her/his gender, age, "race"/ethnicity, sexual identity, and so on, as well as by her/his biography, all of which may inhibit or enable certain research method insights in the field (Hastrup, 1992).

The second set of problems raised by my "failed research" derives from the nature of power relations in the research encounter. My "failed research" taught me that recognizing or even being sensitive to these power relations does not remove them. I would even argue that adopting the role of a supplicant may make it too easy for the researcher to "submerge the instrumental and exploitative elements of participant observation beneath a wave of altruistic intent" (S. J. Smith, 1988, 22). Fieldwork is inherently confrontational in that it is the purposeful disruption of other people's lives. Indeed, anthropologists even speak of the "violence" of fieldwork, even if the violence is symbolic (Crapanzano, 1977; Hastrup, 1992; Rabinow, 1977). In fact, exploitation and possibly betrayal are endemic to fieldwork. This is not to say that the research experience is always a negative one for the researched. Many of the women whom I have interviewed told me that they found the exercise quite cathartic and that it enabled them to reflect on and re-evaluate their life experiences. Despite this I think that fieldwork might actually expose the researched to greater risk and might be more intrusive and potentially more exploitative than more traditional methods (Finch, 1984; Oakley, 1981; Okely, 1992; Stacey, 1988, 1991). Judith Stacey summarizes these worries:

Precisely because (these methods rely) upon human relationship, engagement, and attachment, it places research subjects at grave risk of manipulation and betrayal by the (researcher) ... For no matter how welcome, even enjoyable the fieldworker's presence may appear to "natives," fieldwork represents an intrusion and intervention into a system of relationships, a system of relationships that the researcher is far freer than the researched to leave (Stacey, 1988, 22-23).

Indeed, I am concerned that appropriation (even if it is "only" textual appropriation) is an inevitable consequence of fieldwork. This possibility is uncomfortable for those of us who want to engage in truly critical social science by translating our academic endeavors into political action. Yet, as researchers we cannot escape the contradictory position in which we find ourselves, in that the "lives, loves, and tragedies that fieldwork informants share with a researcher are ultimately data, grist for the ethnographic mill, a mill that has a truly grinding power" (Stacey, 1988, 
23). Like Stacey, I have to admit there have been interviews when I have listened sympathetically to women telling me about the details of their lives (my role as participant) while also thinking how their words will make a great quote for my paper (my role as observer).

At the same time I am not convinced of the viability of some of the popular solutions for dealing with this (textual) appropriation. These include sharing the prepublication text with the researched for feedback and writing "multivocal" texts that "give voice" to the researched by, for example, including lengthy quotes from their interviews. Indeed, some feminists argue that these practices are vital parts of the research process. The intent is to minimize appropriation by avoiding misrepresentation and extending the idea of a reciprocal research alliance between the researcher and the researched. While we can revise our work in response to the reactions of the researched, surely the published text is the final construct and responsibility of the researcher. For example, it is the researcher who ultimately chooses which quotes (and, therefore, whose "voices") to include. Also, is weaving lengthy quotes from interviews into the text a sufficient means of including "others," especially when those quotes are actually responses to unsolicited questions that came about through the researcher's disruption of someone else's life (Okely, 1992; Opie, 1992; Stacey, 1988, 1991)?

So where does all of this leave those who wish to conduct research with integrity about marginalized people? I am, quite frankly, still unsure about the answer to this question. However, at this point my position is this. The first step is to accept responsibility for the research[. A]s Rahel Wasserfall $(1993,28)$ remarks, researchers "cannot pretend to present fully their informants' voices and have to take responsibility for their intrusions both in their informants' lives and the representation of those lives." There also needs to be recognition that the research relationship is inherently hierarchical; this is simply part and parcel of the (conflictual) role of the researcher. I am not saying that we should not adopt strategies to counterbalance this inevitability, but reflexivity alone cannot dissolve this tension. Reflexivity can make us more aware of asymmetrical or exploitative relationships, but it cannot remove them.

Perhaps the [thornier] question is whether, given the inevitability of unequal power relations in fieldwork, we should even be doing this research at all. I think any answer must be equivocal. What I have argued thus far is that the research encounter is structured by both the researcher and the research participants, and that the research, researched, and researcher might be transformed by the fieldwork experience. I want to take this argument a step further. I suggest that we approach the unequal power relations in the research encounter by exposing the partiality of our perspective. I am a straight woman who is sympathetic to the argument that lesbian geographers should do lesbian geography. However, I agree with Linda Peake who has argued that "in their efforts to wrest control of developments in feminist theory (certain Black feminists) are delivering a potent rhetoric of political correctness that can strike panic in feminists who are sympathetic to their concerns" $(1993,419)$. Of course, all the sympathy in the 
world is not going to enable me to truly understand what it is like for another woman to live her life as a lesbian. However, researchers are part of the world that they study; as Dorothy Smith $(1987,142)$ puts it, "Like Jonah, she is inside the whale. Only of course she is one among the multiplicity of subjects whose coordered activity constitute the whale ... she is of and inside the cosmos she seeks to understand." There exists a continuum between the researcher and the researched. We do not conduct fieldwork on the unmediated world of the researched, but on the world between ourselves and the researched. At the same time this "betweenness" is shaped by the researcher's biography, which filters the "data" and our perceptions and interpretations of the fieldwork experience (Hastrup, 1992; Hondagneu-Sotelo, 1988; McDowell, 1992b). So, should I decide to pursue my research project on the lesbian community, it will be in the full knowledge that I cannot speak for them and not myself. What I will be studying is a world that is already interpreted by people who are living their lives in it and my research would be an account of the "betweenness" of their world and mine.

In short, I believe that we need to integrate ourselves into the research process, which admittedly is anxiety-provoking in that it increases feelings of vulnerability. However, as Geraldine Pratt (1992, 241, emphasis in the original) remarks "establishing the grounds for taking a position and the right to speak - for oneself and certainly about others - is by no means unproblematic." I believe it is important to be more open and honest about research and the limitations and partial nature of that research. We need to locate ourselves in our work and to reflect on how our location influences the questions we ask, how we conduct our research, and how we write our research.

\section{Conclusion}

I have discussed the process of making geographies that are sensitive to feminist and poststructuralist challenges to objectivist social science. I explored ethical questions that exist in most research, but are thrown into stark relief when there is an immediate relationship between the researcher and the people being investigated. I began with a critical discussion of neopositivist and feminist/critical methodology. I noted that the latter does not provide a clear set of rules to follow, but a series of "maps" to guide research. I argued that greater reflection on the part of the researcher might produce more inclusive, more flexible, yet philosophically informed methodologies sensitive to the power relations inherent in fieldwork. Hence, I engaged in a reflexive inquiry into a "failed" research project about gender, sexual identities, and space. That process raised further insight into the ethical nature of my research question, especially with regard to the dialogical relationship between the researcher and the researched. Of course, ethical problems, by their very nature, are not easily resolved and the solution that I offered illustrates the situated and partial nature of our understanding of "others." I argued that fieldwork is intensely personal, in that the positionality [i.e. position based on class, gender, race, etc.] and biography of the 
researcher plays a central role in the research process, in the field as well as in the final text.

\section{References}

Adler, S. and J. Brenner. 1992. Gender and space: Lesbians and gay men in the city. International Journal of Urban and Regional Research 16, 24-34.

Bakhtin, M. 1986. The Dialogical Imagination. Austin: University of Texas Press.

Bell, D. J. 1991. Insignificant others: Lesbian and gay geographies. Area 23, 323-29.

Bondi, L. 1990. Progress in geography and gender: Feminism and difference. Progress in Human Geography 14, 438-45.

Burawoy, M. 1991. Reconstructing social theories. In, M. Burawoy, A. Burton, A. Amett Ferguson, K. J. Fox, J. Gamson, N. Gartrell, L. Hurst, C. Kurzman, L. Salzinger, J. Schiffman \& S. Ui (eds.), Ethnography Unbound: Power and Resistance in the Modern Metropolis. Berkeley: University of California Press, 8-27.

Crapanzano, V. 1977. On the writing of ethnography. Dialectical Anthropology 2, 6973.

Crimp, D. 1992. Portraits of people with AIDS. In, L. Grossherg, C. Nelson \& P. Treichler (eds.), Cultural Studies. London and New York: Routledge, 117-33.

de Lauretis, T. 1991. Queer theory: Lesbian and gay sexualities. Differences: A Journal of Feminist Cultural Studies 3, iii-xviii.

D’Emilio, J. 1992. Making Trouble: Essays on Gay History, Politics and the University. London and New York: Routledge.

Douglas, C. 1990. Love and Politics: Radical Feminist and Lesbian Theories. San Francisco: ISM Press.

Driver, F. 1992. Geography's empire: Histories of geographical knowledge. Environment and Planning D: Society and Space 10, 23-40.

Evans, D. 1988. Social interaction and conflict over residential growth: A structuration perspective. In, J. Eyles \& D. M. Smith (eds.), Qualitative Methods in Human Geography. Oxford: Polity Press, 118-35. 
Finch, J. 1984. "It's great to have someone to talk to": The ethics and politics of interviewing women. In, C. Bell \& H. Roberts (eds.), Social Researching: Politics, Problems and Practice. London: Routledge, 70-87.

Folch-Serra, M. 1990. Place, voice, space: Mikhail Bakhtin's dialogical landscape. Environment and Planning D: Society and Space 8, 255-74.

Gamson, J. 1991. Silence, death and the invisible enemy: AIDS activism and social movement newness. In, M. Burawoy, A. Burton, A. Arnett Ferguson, K. J. Fox, J. Gamson, N. Gartrell, L. Hurst, C. Kurzman, L. Salzinger, J. Schiffman \& S. Ui (eds.), Ethnography Unbound: Power and Resistance in the Modern Metropolis. Berkeley: University of California Press, 35-57.

Geiger, S. 1990. What's so feminist about doing women's oral history. Journal of Women's History 2, 169-82.

Geltmaker, T. 1992. The queer nation acts up: Health care, politics, and sexual diversity in the County of Angels. Environment and Planning D: Society and Space 10, 609-50.

Grosz, E. A. 1989. Sexual Subversions: Three French Feminists. Sydney: Allen and Unwin.

Hastrup, K. 1992. Writing ethnography: State of the art. In, J. Okely \& H. Callaway (eds.), Anthropology and Autobiography. London and New York: Routledge, 116-33.

Herod, A. 1993. Gender issues in the use of interviewing as a research method. The Professional Geography 45, 305-17.

Hondagneu-Sotelo, P. 1988. Gender and fieldwork. Women's Studies International Forum 11, 611-18.

Jackson, P. 1991. The cultural politics of masculinity: Towards a social geography. Transactions of the Institute of British Geographers 16, 199-213.

Jackson, P. 1989. Gender and sexuality. In, P. Jackson (ed.), Maps of Meaning: An Introduction to Cultural Geography. Boston: Unwin Hyman, 104-31.

Jackson, P. 1985. Urban ethnography. Progress in Human Geography 9, 157-76.

Knopp, L. 1992. Sexuality and the spatial dynamics of capitalism. Environment and Planning D: Society and Space 10, 651-69.

Knopp, L. 1990. Some theoretical implications of gay involvement in an urban land market. Political Geography Quarterly 9, 337-52. 
Knopp, L. 1987. Social theory, social movements and public policy: Recent accomplishments of the gay and lesbian movement in Minneapolis. International Journal of Urban and Regional Research 11, 243-61.

Laws, G. 1993. The land of old age: Society's changing attitudes toward built environments for elderly people. Annals of the Association of American Geographers 83, 672-93.

Lockard, D. 1985. The lesbian community: An anthropological approach. Journal of Homosexuality 11, 83-95.

Lowe, M. and J. Short. 1990. Progressive human geography. Progress in Human Geography 14, 1-11.

McDowell, L. 1992a. Valid games? A response to Erica Schoenberger. The Professional Geographer 44, 212-15.

McDowell, L. 1992b. Doing gender: Feminism, feminists and research methods in human geography. Transactions of the Institute of British Geographers 17, 399416.

McDowell, L. 1988. Coming in from the dark: Feminist research in geography. In, J. Eyles (ed.), Research in Human Geography. Oxford: Blackwell, 154-73.

Miles, M. and J. Crush. 1993. Personal narratives as interactive texts: Collecting and interpreting migrant life-histories. The Professional Geographer 45, 84-94.

Mills, C. A. and C. W. J. Withers. 1992. Teaching qualitative geography as interpretative discourse. Journal of Geography in Higher Education 16, 159-65.

Moss, P., J. Eyles, I. Dyck and D. Rose. 1993. Focus: Feminism as method. The Canadian Geographer 37, 48-61.

Okely, J. 1992. Anthropology and autobiography: Participatory experience and embodied knowledge. In, J. Okely \& H. Callaway (eds.), Anthropology and Autobiography. London and New York: Routledge, 1-28.

Oakley, A. 1981. Interviewing women: A contradiction in terms. In, H. Roberts (ed.), Doing Feminist Research. London: Routledge and Kegan Paul, 30-61.

Opie, A. 1992. Qualitative research: Appropriation of the "other" and empowerment. Feminist Review 40, 52-69.

Peake, L. 1993. Challenging the patriarchal structuring of urban social space? Environment and Planning D: Society and Space 11, 415-32. 
Pile, S. 1991. Practising interpretative geography. Transactions of the Institute of British Geographers 16, 458-69.

Pratt, G. 1992. Spatial metaphors and speaking positions. Environment und Planning D: Society and Space 10, 241-44.

Probyn, E. 1993. Sexing the Self: Gendered Positions in Cultural Studies. London and New York: Routledge.

Rabinow, P. 1977. Reflections on Fieldwork in Morocco. Berkeley: University of California Press.

Ross, B. 1990. The house that Jill built: Lesbian feminist organizing in Toronto, 19761980. Feminist Review 35, 75-91.

Rowe, S. and J. Wolch. 1990. Social networks in time and space: Homeless women in skid row, Los Angeles. Annals of the Association of American Geographers 80, 184-204.

Ruddick, S. 1994. Homeless in Hollywood: Mapping the Social Imaginary. London and New York: Routledge.

Salholz, E., D. Glick, L. Beachy, C. Monserrate, P. King, J. Gordon and T. Barrett. 1993. Pride and prejudice: Lesbians come out strong. Newsweek June 21, 54-60.

Sidaway, J. D. 1992. In other worlds: On the politics of research by "First World" geographers in the "Third World." Area 24, 403-08.

Smith, D. 1987. The Everyday World as Problematic: A Feminist Sociology. Boston: Northeastern University Press.

Smith, N. 1993. Homeless/global: Scaling places. In, J. Bird, B. Curtis, T. Putnam, G. Robertson \& L. Tickner (eds.), Mapping the Futures: Local Cultures, Global Change. London and New York: Routledge, 87-119.

Smith, S. J. 1988. Constructing local knowledge: The analysis of self in everyday life. In, J. Eyles \& D. Smith (eds.), Qualitative Methods in Human Geography. Cambridge: Polity Press, 17-38.

Stacey, J. 1991. Can there be a feminist ethnography? In, S. Berger Gluck \& D. Patai (eds.), Women's Words: The Feminist Practice of Oral History. New York and London: Routledge, 111-19.

Stacey, J. 1988. Can there be a feminist ethnography? Women's Studies International Forum 11, 21-27. 
Stanley, L. and S. Wise. 1993. Breaking Out Again: Feminist Ontology and Epistemology. London and New York: Routledge.

Valentine, G. 1993a. Desperately seeking Susan: A geography of lesbian friendships. Area 25, 109-16.

Valentine, G. 1993b. Negotiating and managing multiple sexual identities: Lesbian time-space strategies. Transactions of the Institute of British Geographers 18, 237-48.

Warren, C. A. B. 1988. Gender Issues in Field Research. Newbury Park, CA: Sage.

Wasserfall, R. 1993. Reflexivity, feminism and difference. Qualitative Sociology 16, 23-41.

Wekerle, G. 1988. Canadian women's housing cooperatives: Case studies in physical and social innovation. In, C. Andrew \& B. Moore Milroy (eds.), Life Spaces: Gender, Household, Employment. Vancouver: University of British Columbia Press, 102-40.

Winchester, H. and P. White. 1988. The location of marginalised groups in the inner city. Environment and Planning D: Society and Space 6, 37-54.

Woolf, V. 1938. Three Guineas. New York: Harcourt Brace Jovanovich. 